\title{
小児慢性副鼻腔炎における上顎洞集中洗浄療法の効果
}

\author{
三重大学医学部耳鼻咽喉科学教室 (主任：坂倉康夫教授) \\ 西井さつき, 間島雄一, 野々山勉, 岡田英作 \\ 高橋志光, 湯田厚司, 坂倉康夫
}

\section{EFFECTS OF FREQUENT ANTRAL LAVAGE ON CHRONIC SINUSITIS IN CHILDREN}

SATSUKI NISHII, M.D., YUICHI MAJIMA, M.D., TSUTOMU NONOYAMA, M.D. EISAKU OKADA, M.D., YUKIMITSU TAKAHASHI, M.D., ATSUSHI YUTA, M.D. and YASUO SAKAKURA, M.D.

Department of Otorhinolaryngology, Mie University School of Medicine, Tsu

Eighty cases of pediatric sinusitis (4 to 15 years old, averaged 8 years old) were treated with frequent antral irrigations. Antral puncture was made through the inferior meatus with a Kyoto University needle under topical or general anesthesia. Then a plastic tube of $14 \mathrm{G}$ Medicut ${ }^{\circledR}$ intravenous canula was left in place to serve as an indwelling catheter. Antral lavages were performed through this tube 3 times daily for 7 to 10 days.

The opacity of the maxillaly sinus at post-treatment was improved significantly compared with that at pre-treatment in Waters view. This improvement was continued even at about 5.7 months after treatment. The opacity of the ethmoid sinus was also improved significantly after the treatment in occipito-frontal view. Our results suggest that the frequent antral lavage is an useful therapeutic modality for pediatric sinusitis.

少慢性副鼻腔炎, 上顎洞洗浄療法

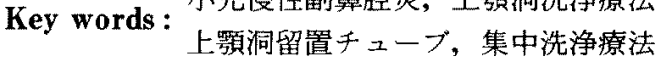

A $94-1694-33137$

$$
\text { Iはしかに }
$$

近年小児の慢性副鼻腔炎は減少傾向にあり特に高度 の化膿型は著しく減少してきているとされている が1)，学童生徒の学校検晾では約 3\%の有病率をみと $\bigotimes^{2)}$, な㧍日常臨床上重要な疾患である. 三重大学耳鼻 咽喉科では1980年12月より副鼻腔外来を設け，特に15 歳未満の小监の上颚洞病変に対し通院による上䪽洞洗 净を行っている として週 1 回施行し，改善傾向にある症例では洗浄問 隔を渐次延長してゆくのであるが，通院距離が遠く治 療を継続して受けることが不可能な症例も存在する。 また穿刺・洗浄療法に抵抗するため，これが不可能な 症例も存在する。このように外来での上枵洞洗浄の不
可能な小児に対しては集中洗淨療法と称して入院のう え，1日3回の上顎洞洗浄を 7〜10日間施行している. 本編では小児慢性副鼻空炎に対する集中洗浄療法の方 法と治療効果について報告する。

\section{II . 対象と病変の診断, 治療方法}

\section{1. 対象}

1982年 3 月より 1988 年 4 月までの 6 年間に三重大学 医学部耳鼻咽喉科に入院，集中洗净療法を受けた小児 慢性副鼻腔炎患者80名 (男児45名，女児35名) 153側の 副鼻腔を対象とした。

2. 上䫑洞集中洗浄療法

京大式探膿針にて下鼻道側壁より上頱洞穿刺を行つ 


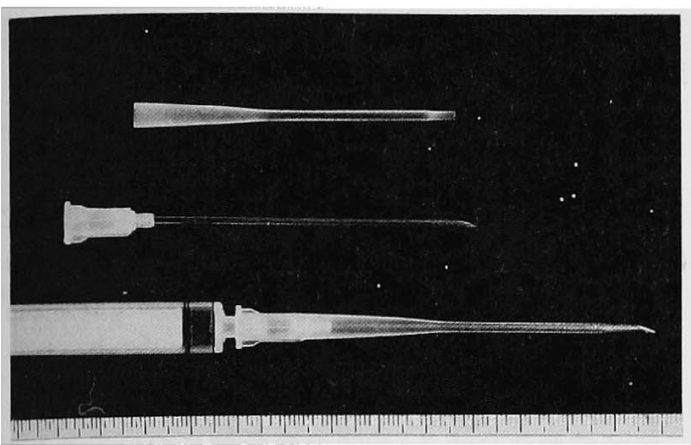

図 1 静脈用カニューラ

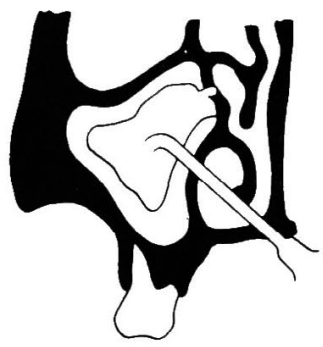

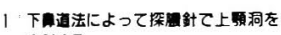
冴する.
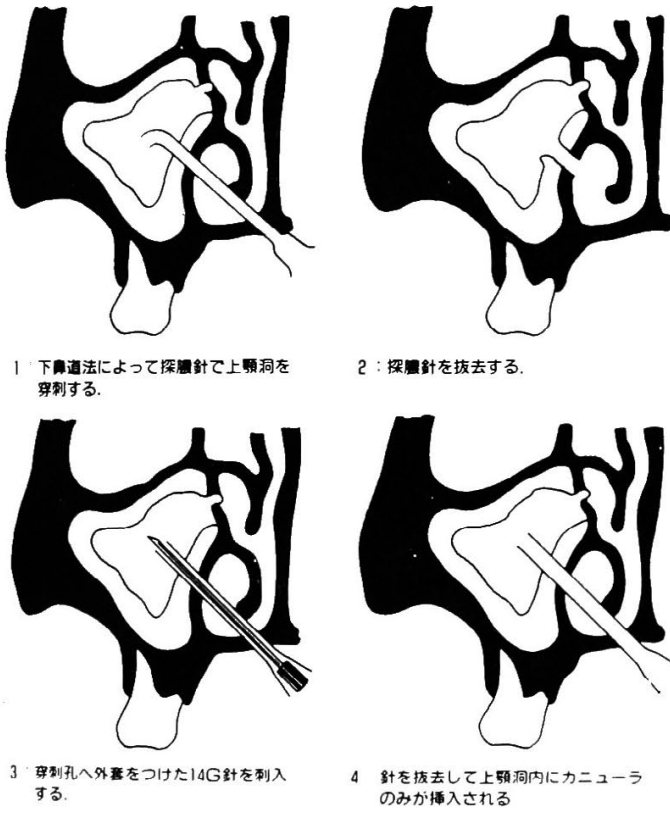

2：探凰针を抜去する。

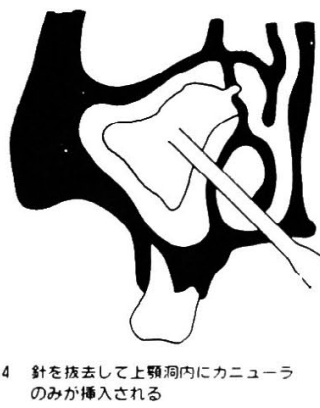

図 2 静脈用カニューラの挿入手技

た後, 探膿針を抜去し直ちに静脈用カニューラ (argyl MEDICUT ${ }^{\circledR} 14$ ゲージ)（図 1) を穿刺部位に 挿入して外套のプラスチックチューブを上頢洞に留置 固定する4) (図 2)。このチューブを利用して 1 日 3 回 生理的食塩水 $100 \mathrm{ml}$ にて洗浄, 1 日 1 回硫酸ジべ力シ ン $40 \mathrm{mg}$, デキサメタゾン $0.38 \mathrm{mg}$ を含む生理的食塩 水 $2 \mathrm{ml}$ を洞内に注入する.洗浄は原則として 7 日間施 行した。

プラスチックチューブの留置固定は症例に応じて全 身麻酔下または局所表面麻酔下に施行した。なお，鼻 茸を認める症例には鼻内より鼻茸を摘出し，1986年以 降では篩骨洞に高度陰影を認める症例には鼻内より前 部篩骨洞の開放を行った。またアデノイド増殖症を認
表 1 アンケート調査の設問

1. 該当するものに○をつけて下さい

1）鼻汁の量は治療前に比心゙

きわめて改善

- 改善

- 変 5 す

- 悪化

2）鼻汁がのどに流れるのは きわめて改善

- 改善

変らず

- 悪化

3）鼻づまり

きわめて改善

改善

・変らず

- 悪化

4）頭の重い感じや頭痛はききわめて改善

- 改善

・変らず

- 悪化

2. 集中洗浄療法を受けたことについて

(1) 治療を受けてよかった

(2) 治療を受けなければよかった

(3) どちらともいえない

めた場合，積極的にアデノイド切除術を加えた。

3. 病変の診断と治療効果の評価

a. 単純 $\mathrm{X}$ 線撮影検查

上顎洞，篩骨洞の病変はウォータース法及び後頭前 頭法により撮影された副鼻腔陰影を文部省総合班研究 による X 線読影基準 ${ }^{5)}$ に従い(一)，(士)，(+)，(+)， （卅）の5段階に分類し, 治療前, 治療直後及び退院 後 1 ～43力月後（平均 5.7 力後）について比較した。 なお読影の信頼性を高めるため 1 人の医師がすべての X 線を読影した。

b. $\mathrm{X}$ 線的上顎洞粘膜機能検査 $(\mathrm{X}-\mathrm{MFT})$

隠明寺 ${ }^{6)}$ の定めた次の 6 型で表現した。びまん型及 び準びまん型を軽度, 斑紋型・びまん限局型を中等度, 限局型・分散型を高度病変と分類した ${ }^{7)}$.

c. アンケート調査

本治療法効果に対するアンケート調査を施行した。 1986年 4 月より 1988年 4 月までの間に加療した35名を 対象として表 1 のごとく, 治療後の鼻漏, 後鼻漏, 鼻 閉, 頭重感に及ぼす効果と集中洗浄療法を受けたこと に対する印象を1988年 8 月アンケート調査した（表 1).

4. 統計学的検討 
治療前後の洞病変の変化は対応のある Wilcoxon 検 定により有意差の有無を検討した。

III. 結果

1. 年齢分布

図 3 に集中洗浄療法を受けた患者構成を示す，年齢 分布は $4 \sim 15$ 歳で 6 歳に最も多く平均年齢は 8 歳であ つた.

2. 治療方法

表 2 に80名の対象患者に施行された治療方法を示し た。鼻・副鼻腔に関しては集中洗净療法のみ66例( 82.5 \%)，これにポリープ切除を行ったもの3 例, 鼻内篩骨 洞開放術を行ったもの9例，ポリープ切除と鼻内笁骨 洞開放術を併せて行ったもの2例であった。俢出性中 耳炎やアデノイド增殖症，慢性扁桃炎を合併した症例

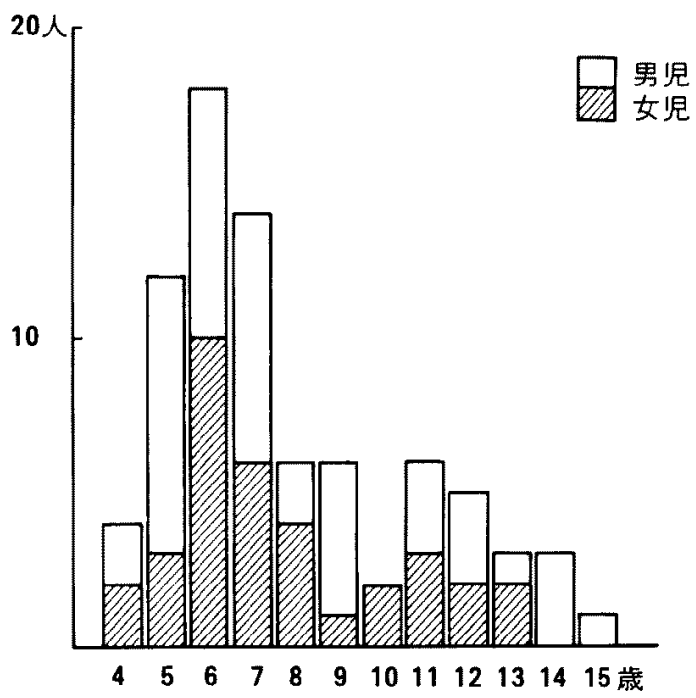

図 3 年齢分布
も多く鼓膜チューブ留置，アデノイド切除術，扁桃摘 出術を併用したものが54例，68\%にみとめられた。

3. 治療前の検查結果

a. 上顎洞陰影について

治療前のウォータース法による148側の上䋶洞病変 は (-) 5 側，（土）12側，(+) 38側，(+) 85側，（卅) 8 側であった（サ）を示したものが最多で57\%を占 め，(+）及び（\#）を示したものが83\%であった。

b. 篩骨洞陰影について

後頭前頭法による149側の篩骨洞についてみると （一）16側，（士）36側，（+）41側，（+) 53側，（卅）

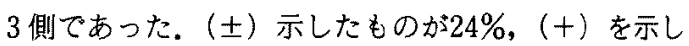
たものが $28 \% （$ （サ）を示したものが36\%であり軽度陰 影から高度陰影まで広く分布していた。また陰影を認 めないものが10\%を占めた。

\section{c. X-MFT}

治療前に X-MFT を施行した104側の上頻洞病変は びまん型 4 側，準びまん型19側，斑紋型14側，びまん 限局型 34 側, 限局型 22 側, 分散型11側て, 軽度病変が

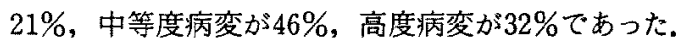

3. 治療効果

上顎洞集中洗浄療法を施行した153側の副鼻腔につ いて治療効果検討した，洗浄期間は $5 \sim 10$ 日間と症 例により異なっていた。

a. 上顎洞陰影に及ぼす効果

治療前と集中洗浄療法直後にウォータース法により 上顎洞陰影を検索し得た 65 側について比較すると治療 直後有意に陰影の改善を認めた $(p<0.01$ ) (図 4-A). また治療直後と退院後 (平均5.7力月後) の上䫑洞陰影 を比較することができた37側では両者間に有意差は認 められなかった（図 4-B）.

上䫑洞集中洗浄療法の有効例を示す．症例は 4 藏男

表 2 治療方法

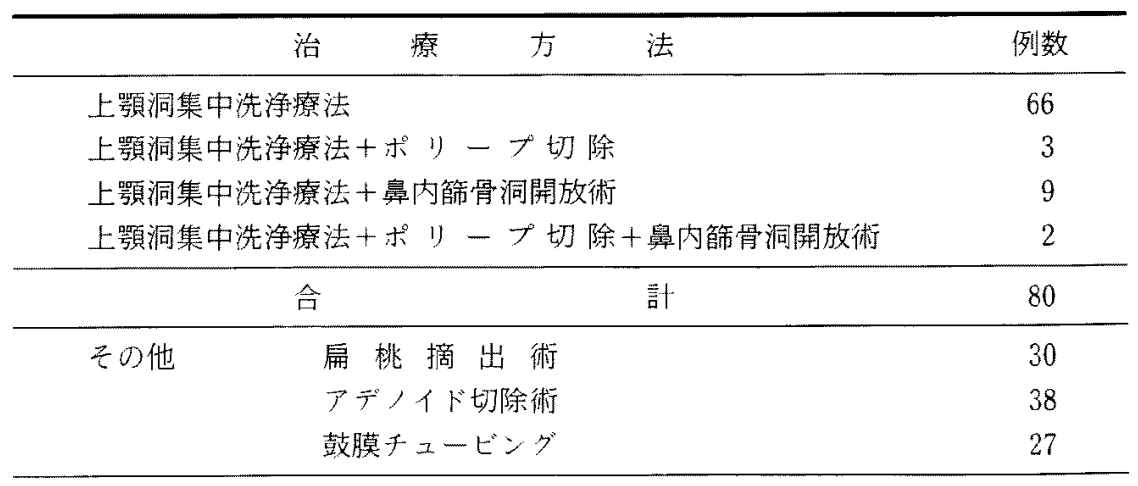




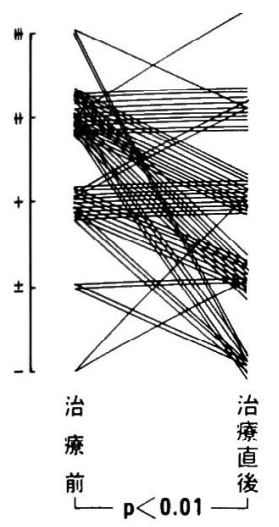

A

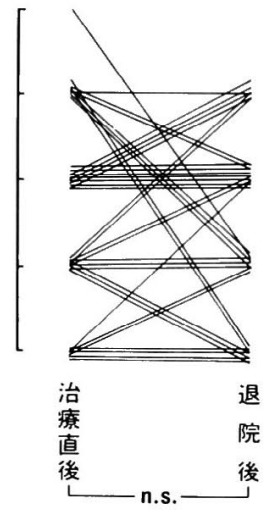

B

図4集中洗浄療法の上顎洞陰影に及ほす効果

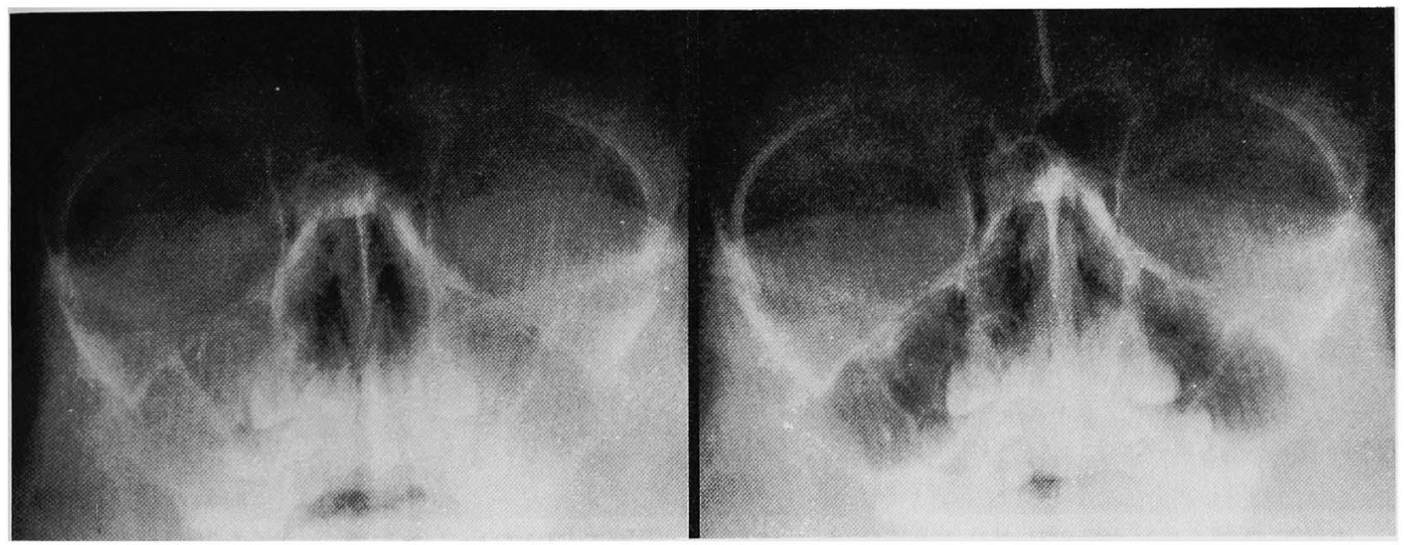

治 療 前

子, 膿性鼻漏のため来科し, $\mathrm{X}$ 線上両側上顎洞（卅） と判定した (図 $5 \mathrm{~A}$-左)。9日間の集中療法により症 状は改善し, 上顎洞陰影も改善, 消失した (図 $5 \mathrm{~A}-$ 右). しかし篩骨洞については改善がみられなかった（図 5 B).

b. X-MFT に及ぼす効果

治療前と治療直後で X-MFT を施行し比較のでき た49側の上頡洞では治療後 X-MFT は有意に改善し た $(\mathrm{p}<0.01)$ （図 6$)$ ．高度病変を示した 10 側中 3 側が 中等度病変に， 7 側が軽度病変に改善を認めた。

c. 篩骨洞病変

以下の検討は鼻内篩骨洞開放術を施行した症例を除 き，上顎洞集中洗浄療法のみを施行した例について検 討した，治療前と治療直後に後頭前頭法により管骨洞 病変を比較検討しえた 63 側では治療直後，治療前に比

図 $5 \mathrm{~A}$ 症例（4歳男子）ウォータース法

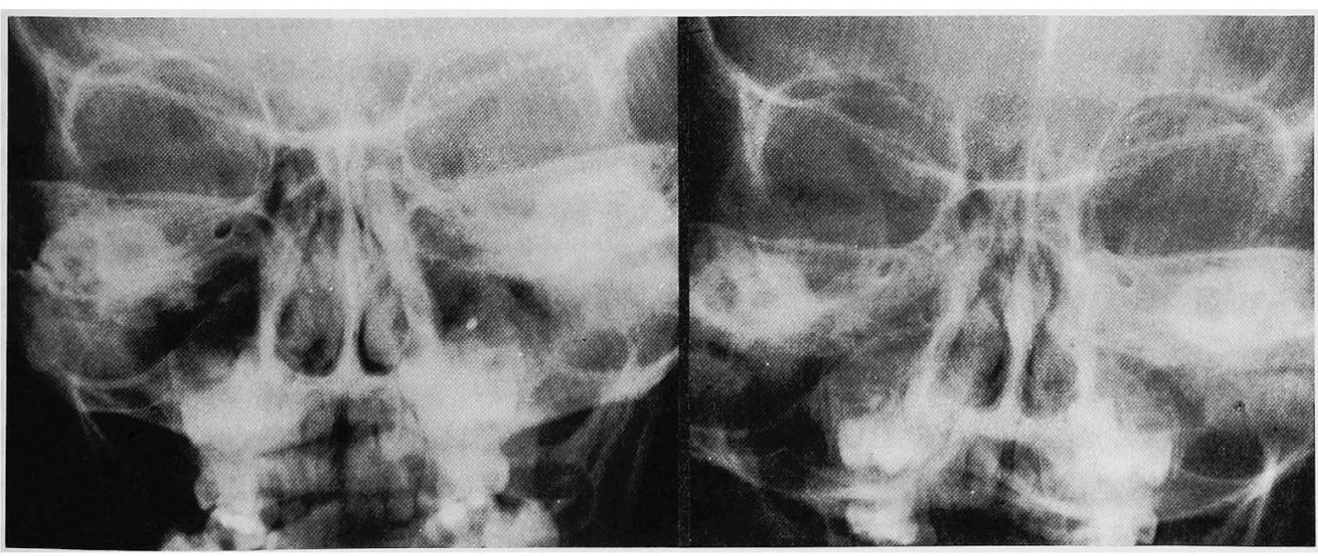

治 療前
治 療後

図 5 B 症例（4 歳男子）後頭前頭法 


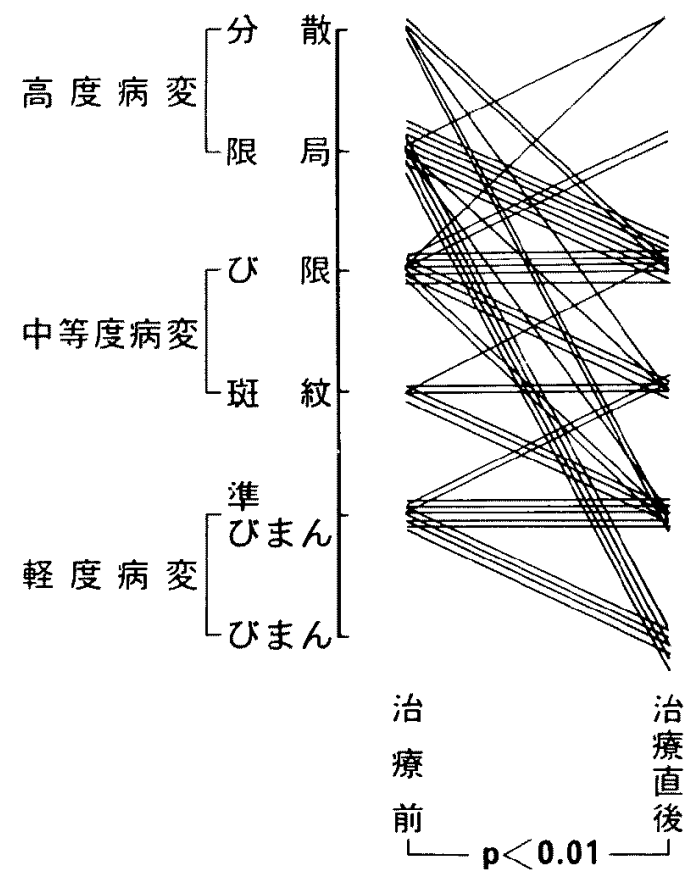

图 6 集中洗浄療法のX-MFT に及ほすす効果

し有意に改善を認めた（p<0.01）（図 7-A）。また治 療直後と退院後 (平均5.7力月後)を比較しえた 30 側に おいても退院後の篩骨洞陰影は治療直後に比し有意に 改善を認めた $(\mathrm{p}<0.05)$ (図 7-B).

篩骨洞陰影の改善例を示寸。症例は 6 歳女子, 膿性 鼻漏のため来科し， $\mathrm{X}$ 線上両側上顎洞 $(\#)$ (図 $8 \mathrm{~A}$ 左), 画側篩骨洞 (H) (図 8 B-左) と判定した。10日 間の洗浄療法にて上領洞陰影は $(+)$ と改善傾向を認 め(汹 $8 \mathrm{~A}$-右)，また篩骨洞陰影は著明に改善，消失 した(図 8 B-右).

d. アンクート調查

アンケート調直の回答率は $94 \%$ であった。自党症状 の改善（著効十有効）は鼻漏 $64 \%$, 後鼻漏 $39 \%$, 鼻閉 57\%，頭重感59\%であり特に鼻漏と頭重感に改善がみ とめられた，集中洗浄を受けたことに対しては70\%が 受けてよかったと回答した（図 9 ).

\section{IV. 考察}

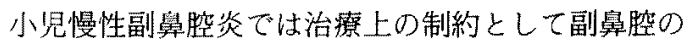
発育が完成していないので，特に上顎洞に対しては可 能な限り根本手術をさけ，保存的療法によって治療せ ねばならない，一般に第 2 小罡がはえる10歳まで上 頻洞手術は禁忌されているが，さらに洞の発育が完成

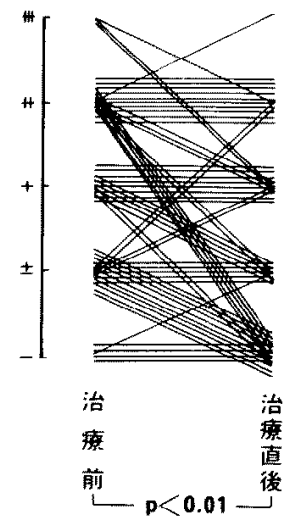

A

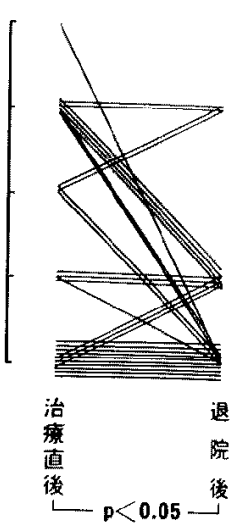

B
図 7 集中洗浄㙩法の笁骨洞陰影に及仿す効果

する15歳までは同部位への手術侵襲はできるだけ避け るべきである゙．このような小児に対し上顓洞穿刺・洗 浄療法は極めて有効な保存的手段であるが，遠隔地に 在住していて通院困難な場合や患者が幼小児で外来で 行う繰り返しの穿刺・洗浄療法が不可能な症例に対し ては集中洗浄療法が有効な手段と考えられる。.上額洞 内にカテーテルを㨉入し，頻回に洗浄を行う本法の歴 史は古くそして新しい。土田”らによると古くは1925 年の shea の報告が初めてといわれている。近年では $\mathrm{Ahmad}^{10)}$ らは Drettner ${ }^{11)} ら の$ 新しい留置チューブ考 案についての報告がみられている。我々が今回使用し た静脈用力ニューラは挿入に際し鼻・副鼻腔に大きな 侵襲を加えないこと，チュープの先端が鼻入口部より 少し突出するのみであることから患者に不快感や異物 感を与えないこと，愦って脱落した場合，再挿入が容 易である利点を有している。

集中洗浄療法を含めた上䂓洞洗浄療法加慢性副鼻腔 炎の治療に有効な理由として次のように考えられてい $3^{8121}$ (図10). 感染を契機としてその炎症産物は組織 阻害を薏起し，粘液瀻毛機能障害が生じる，また炎症 産物が引き金となり異常なレオロジー的性質を有する 粘液の分泌元進が生じ、これもまた粘液緎毛機能障害 を生じる。このような粘液緎毛機能の低下法洞への分 泌物の停滞につながる，炎症による鼻・副悬腔粘膜の 浮腫・腫脹は自然孔の㹨窄，閉鎖を生し，洞の換気不 全を惹起して洞への分泌物停滞を助長する，洞内に停 滞した分泌液中には蛋白分解酵素，種々のメディエー 夕一．免疫複合体，細菌由来物質が含まれており，こ れらが組織障害を起こすことにより悪循環が形成され 


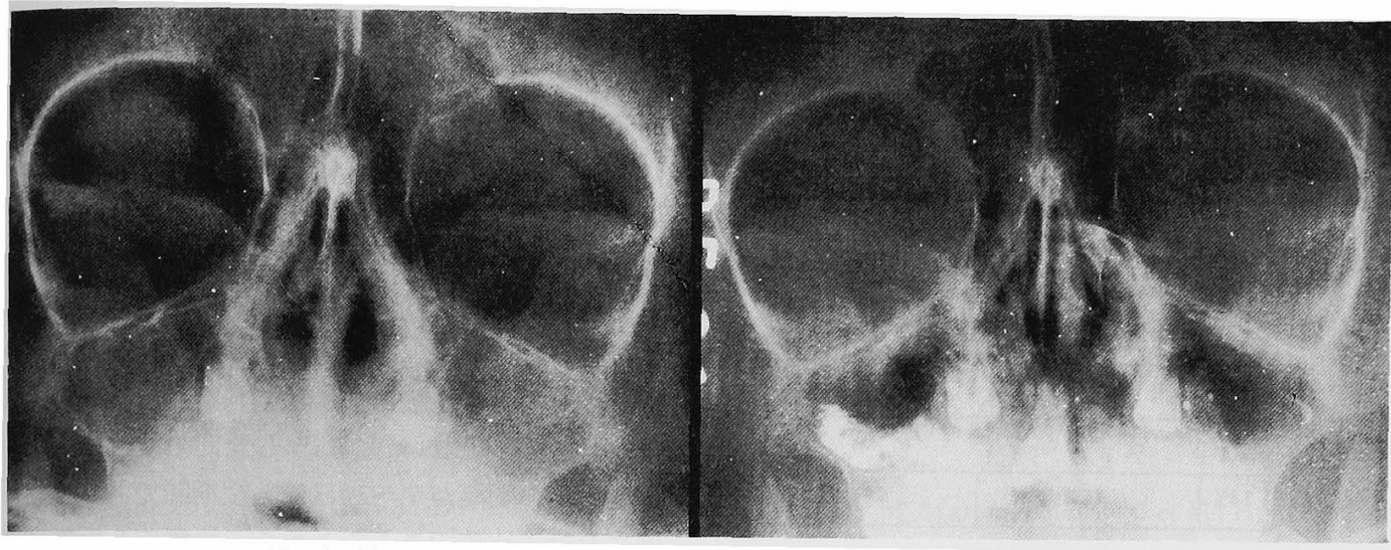

治 療 前

治 療 後

図 $8 \mathrm{~A}$ 症例（6歳女子）ウォータース法

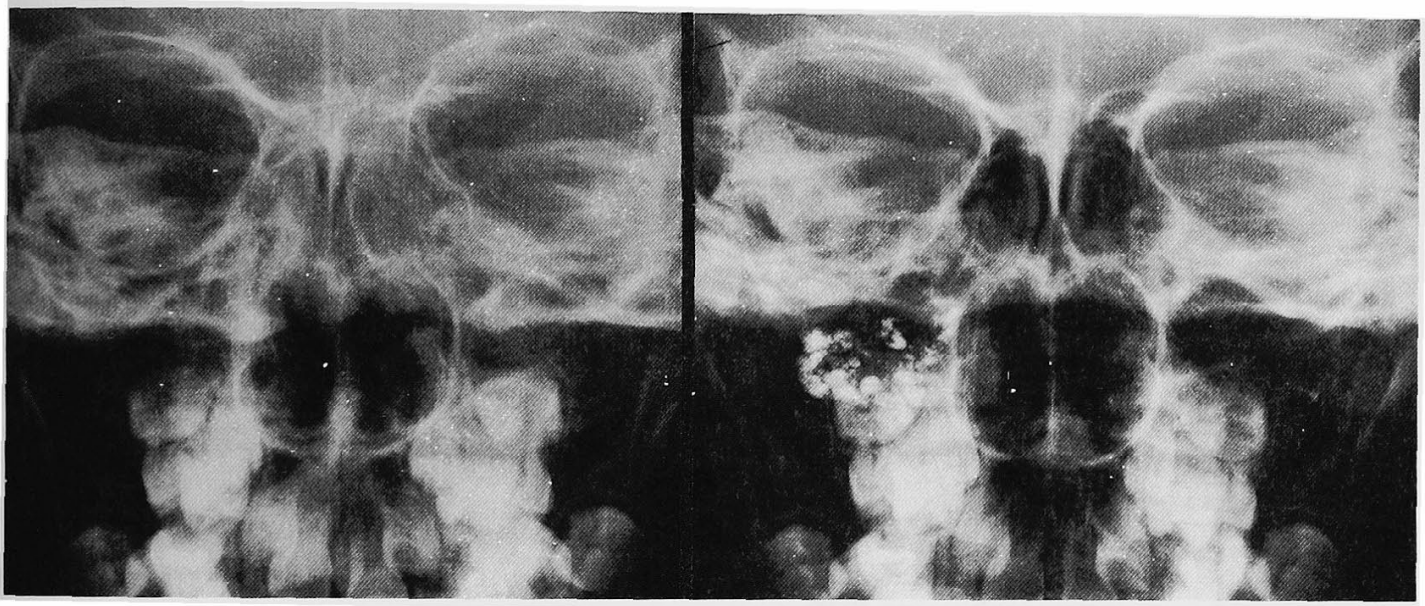

治療前

治 療後

図 $8 \mathrm{~B}$ 症例（6 歳女子） 後頭前頭法

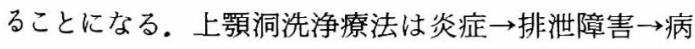
的気道液貯留 $\rightarrow$ 貯留液成分による自己損傷 $\rightarrow$ 炎症の悪 循環をたちきる臨床的に実際的な手段といえよう。と くに集中洗浄療法は頻回に洗浄することにより洗浄中 は洞内への病的気道液の貯留を阻止する効果が高い.

上顎洞集中洗浄療法の上顎洞病変に対する効果を治 療前と治療直後とで比較してみるとウォータース法, X-MFTによる判定ともに洗浄療法直後では治療前 に比し有意に改善をみとめた、またウォータース法判 定で治療直後と治療後平均 5.7 月の上顎洞病変に有 意差をみとめなかったことより, 集中洗浄療法直後に 改善した上顎洞病変はその後も改善している症例が多 いことが示唆された。

なお, 本統計には集中洗浄療法後, 通院で穿刺・洗
浄療法を続けている症例を一部含んでいる，著者らは 集中洗浄療法で治療を終了するよりも退院後も一定間 隔で上顎洞穿刺・洗浄療法を継続する方がより症状や 病変の改善に効果的ではないかと考えている. 退院後 も継続するか否かの目安は X 線所見で退院後 $1 \sim 2$ 週目にX 線撮影を施行し, 上顎洞陰影が軽度ならこの 時点で治療を終了する. 陰影を認める場合には $1 \sim 2$ 週間隔で穿刺・洗浄を施行し, 洗浄液中に粘性, 粘膿 性または膿性貯留液所見を認める場合には洗浄所見が 清明になり，この状態がその後 $3 \sim 4$ 回の洗浄におい ても持続する場合に洗浄間隔を延長するか治療を終了 するのが理想的である。

治療前にX-MFT で高度病変を示した上顎洞では 治療直後 $90 \%$ が中等度または軽度病変に改善してお 
問 1 に対する結果

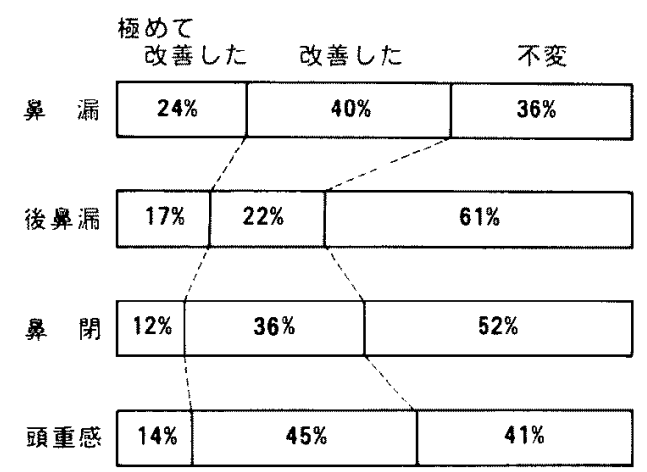

問 2 に对する結果

集中洗浄療法を受けたことについて 治療をうけてよかった $70 \%$ 治療をうけなければよかった ゼちらでもない

$27 \%$

図 9 アンケート調查よりみた上䫑洞集中 洗浄療法の効果

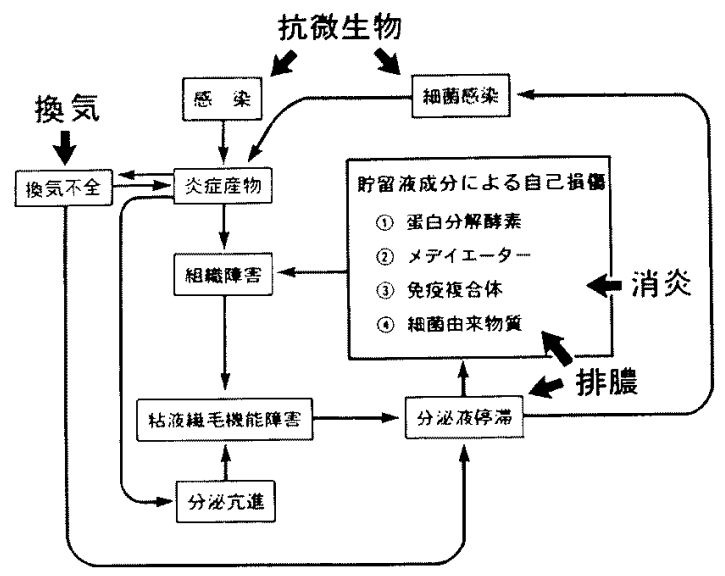

図10 慢性副鼻腔炎に扔ける悪循環の形成と その対策

り，上顎洞陰影の高度または中等度病変例が本法の適 応と考えられた。な㧍今回の検討では，中高度病变 例の不変または悪化例に対しては詳細な検討をなし得 なかった。紐菌学的検査については中鼻道分泌物の唡 出菌と上頢洞貯留液の検出菌が必ずしも一致しないこ $と^{13)}$ ，また本治療では上頻洞穿刺と同時に留置チュー ブを㧴入し洗浄，薬剤の注入を開始することから，治 療期間中に穿刺時に採取した貯留液の細菌学的検査結 果を有効に利用することが困難な場合が多く，このた め第一選択真として硫酸ジべカシンを使用した。治療
成績の一層の向上のためには個々の症例の細菌学的成 績にもとづいて注入薬の選択が必要であろうが，本治 療の理念は上顎洞への病的気道液の貯留を避けること にある。なおステロイド製㓣はその抗炎症作用と分泌 抑制作用 ${ }^{14)}$ を期待して投与を行った。

鼻内篩骨洞手術を併用せず上顎洞洗浄療法のみを施 行した症例の穊骨洞陰影は治療前に比し治療淔後に有 意に改善した。小児の篩骨洞は蜂巣の含気が不十分て ありその病変を後頭前頭法で判定した場合の信賴性 は決して高くはない ${ }^{15)}$. しかし今回の検討は治療前と 治療淔後の間隔が $7 〜 10$ 日間と短期間であり, 同一症 例における比較であることから，治療前と治療直後の 洞陰影の变化は信頼できるものであるといえよう.す なおち上影洞集中洗浄療法は症例に上り篩骨洞病変を 改善しうるものと考えられる。この改善は上枵洞病変 や鼻腔病変の改善による篩骨洞への間接的な影響によ るものであ万う．集中洗浄療法が管骨洞病変に有利に 㗢くとはい元，治療後における篩骨洞病変の不変例も 多い。すなわち本法は篩骨洞病変に対する直接的かつ 確実な治療法ではない．1986年以降，当教室では篩骨 洞病変に対する確実な治療を行うため，集中洗浄療法 を目的に入院した小児で高度の篩骨洞病変を有するも のに対しては，積極的に鼻内節骨洞開放術を同時に施 行するよう試みている。

$$
\mathrm{V} ま と ぬ
$$

集中洗浄療法を施行した小児慢性副鼻腔炎患者80名 につき統計学的検討を加えた。

1） X-MFTによる上顎洞病変では中等度病変が 最も多く $(46 \%)$ ，ついで高度 (32\%), 軽度 $(21 \%)$ であった。

2）上頻洞集中洗浄療法によりウォータース法によ る上顎洞陰影及び X-MFT 所見は治療前に比し治療 後にて有意に改善した。

3）後頭前頭法に上る篩骨洞陰影は集中洗浄療法後 治療前に比し有意に改善した。

4）上枵洞集中洗浄療法に対する自覚症状のアンケ 一ト調查では，改善率が鼻漏64\%，後鼻漏39\%，鼻閉 57\%, 頭重感59\%であった。

以上より集中洗浄療法は小児の慢性副鼻整炎の治療 に有効な手段であると考えられた。

\section{参考文献}

1）島田和哉, 佐野真一, 山口展正, 小沢 仁：日本の嚳疾 
患の現状と将来（その1）嶨疾患の国内文献による考 察. 耳展 22:69-76, 1979 .

2）浜口幸吉, 三吉康郎, 坂倉康夫, 鵜飼幸太郎, 山際幹和 他：当教室に打ける8年間の学校検診の統計学的椮 討. 耳离臨床 74：1072-1080，1981.

3）野々山勉, 間島雄一, 西井きつき, 岡田英作, 高橋志光

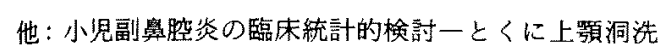
浄癔法について一。目䀧 $93: 355-360.1990$.

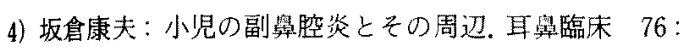
1337-1342，1983.

5）馬場廣太郎, 佐藤克宏, 武田哲男, 古内一郎: 慢性副鼻 空炎の份類について. JOHNS 3: 177-182, 1987.

6) 隠明寺 覚: 慢性上頙洞炎のレ線的機能的研究. 耳展 1 (補 2): 72-131，1958.

7) 足川力雄：上顎洞陰影の定量化如ついて（X-M.F.T. を中心として)。鼻科学臤床所見の定彗化. 熊沢忠躬, 野村恭也 編, 金原出版, 東京, 153-161，1985.

8)間島雄一, 坂倉康夫: 小㫛の上影洞穿刺洗浄法. JOHNS $6: 361-366,1990$.

9）土田好子, 市村恵一, 洲崎春海, 島一晴: 上顎润内 カテーテル挿入による小児慢性副舅腔炎治療の試み。
耳㬋 $50: 1087-1091,1978$.

10) Abdel-Salam AS, Gibb AG: Split cannula-Foley catheter technique in maxillary sinusitis. J Laryngol Otol $95: 221-223,1981$.

11) Drettner $B$, Wibom $C$, Fondverg $L$ : Instrument for antral irrigation with an indwelling plastic tube. Acta Otolaryngol (stockh) Suppl 421:126-127, 1984.

12）坂倉康夫：上気道液 0 生理と病熊. 協和企画通信, 東 京, 1989 .

13）藤巻 豊：慢性副珟腔炎と細菌. JOHNS 3: 167-171, 1987.

14) Kaliner $M$, Maron $Z$, Patow $C$ et al : Human respiratory mucus. J Allergy Clin Immunol $73: 318-322$, 1984.

15）李 華植, 間島雄一, 坂含康夫, 稻垣政志, 杉山洋子 他：小児慢性副蕆空炎の单純レ線像上CT像との比 較。日耳鼻 $94: 1250-1256 、 1991$.

(1990年 9 月12日受稿 1991年6月5日受理)

別刷請求先 $=510$ 四日市市塩浜町 1

三重県立総合塩浜病院耳舆咽喉科 西井さつき 